\title{
Aus dem Leben
}

\section{London Eye}

In einer Kapsel

Sehr sicher eingeschlossen

Geht es gen Himmel

Alle haben Zeit

Um ringsherum zu schauen

dkkuenzler[at]bluewin.ch

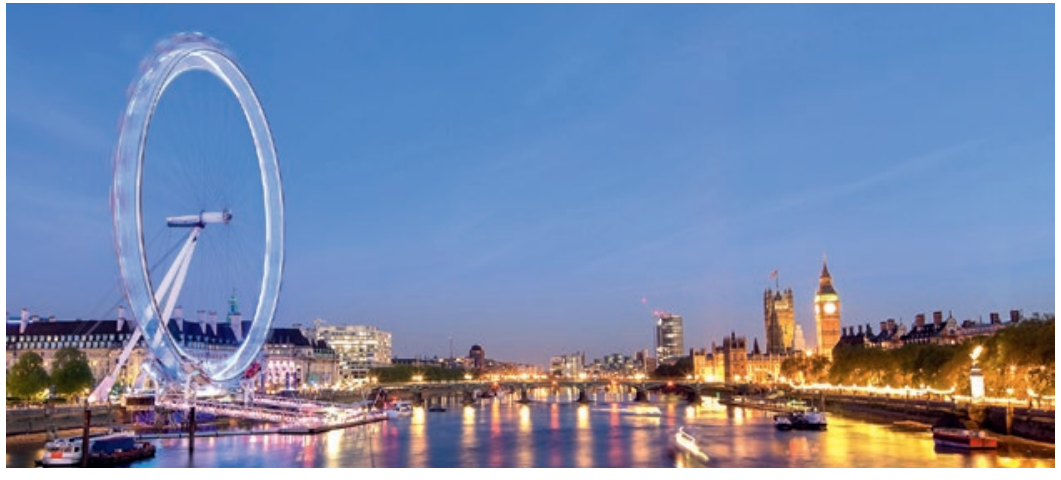

Blick auf London Eye und Big Ben in der Dämmerung (๑ Ollirg | Dreamstime.com).
Unmerklich schwebt man

Der Kulmination zu

Sehr weich und ganz sanft

Zualleroberst

Verweilen wir lediglich

Einen Augenblick

Die langsame Fahrt

Zeigt uns auf Gottes Erde

Was Menschen schufen

Und langsam sachte

Dreht sich der Flug zur Erde

Zur glatten Landung

(2004)

Dr. med. David Künzler, Affoltern am Albis

\section{Nebel}

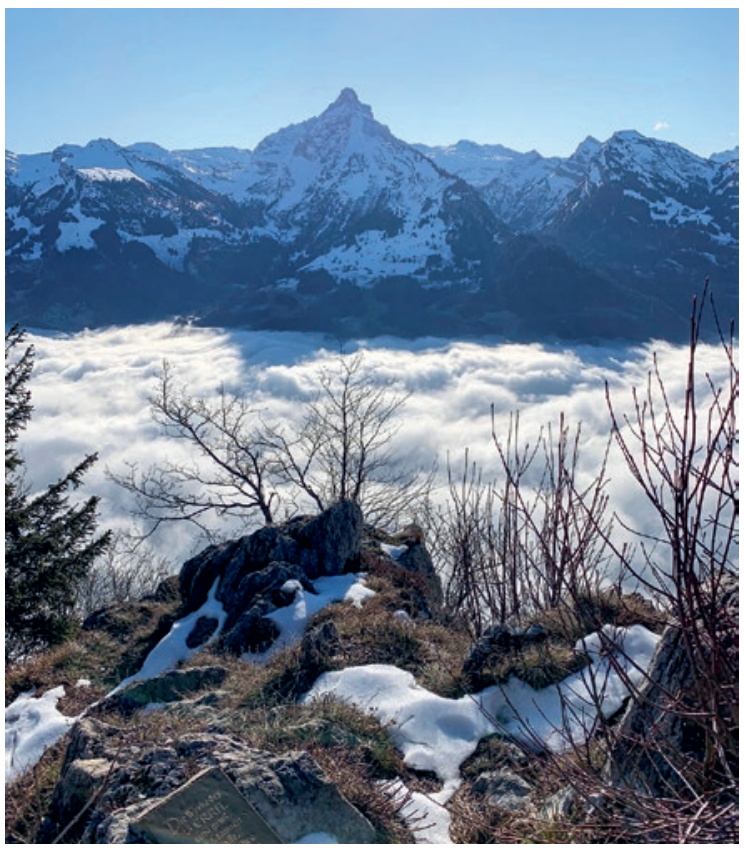

Chapf im Arvenbühl ob Amden (ㄷ Hedi Meierhans).
Nebel ist herrlich

Wenn man besonnt darüber

Steht und staunen kann.

Staunen über die

Sonne ohne die es das

Wunder nicht gäbe

Wir sind Kinder der

Sonne und der Erde, wir

Vergessen es oft.

Aber das ewig

Weibliche zieht uns hinan

Spürt der Poet.

Dr. med. Hedi Meierhans, Maseltrangen 